\title{
Luminescence characteristics of strontium borate phosphate phosphors
}

\author{
Chung-Hsin Lu*, S.V. Godbole ${ }^{1}$, V. Natarajan \\ Electronic and Electro-optical Ceramics Lab, Department of Chemical Engineering, National Taiwan University, Taipei, Taiwan, ROC
}

Received 29 September 2004; received in revised form 24 February 2005; accepted 11 April 2005

\begin{abstract}
New green emitting phosphors based on $\mathrm{SrBPO}_{5}$ with high brightness are prepared via solid-state reactions at high temperatures in reducing atmosphere. $\mathrm{SrBPO}_{5}$ doped with trivalent terbium ions emit weakly in blue and orange light region and strongly in green light region on excitation at $220 \mathrm{~nm}$. The blue and green-orange emissions are ascribed to ${ }^{5} \mathrm{D}_{3} \rightarrow{ }^{7} \mathrm{~F}_{J}$ and ${ }^{5} \mathrm{D}_{4} \rightarrow{ }^{7} \mathrm{~F}_{J}$ (where $J=3-6$ ) transitions of $\mathrm{Tb}^{3+}$ ions, respectively. The co-doping of $\mathrm{Ce}^{3+}$ and $\mathrm{Tb}^{3+}$ in $\mathrm{SrBPO}_{5}$ phosphors results in strong emission from $\mathrm{Tb}^{3+}$ ions on excitation in the UV region corresponding to excitation bands of $\mathrm{Ce}^{3+}$ ions. The enhanced luminescence observed in $\mathrm{Sr}_{0.94} \mathrm{~Tb}_{0.01} \mathrm{Na}_{0.05} \mathrm{BPO}_{5}$ and $\mathrm{Sr}_{0.89} \mathrm{~Tb}_{0.01} \mathrm{Ce}_{0 \cdot 05} \mathrm{Na}_{0.05} \mathrm{BPO}_{5}$ phosphors is understood as due to a reduction in the non-radiative energy transfer. $\mathrm{Sr}_{0.89} \mathrm{~Tb}_{0.01} \mathrm{Ce}_{0.05} \mathrm{Na}_{0.05} \mathrm{BPO}_{5}$ synthesized in reducing atmosphere show nearly two-order enhancement in emission intensity of $542 \mathrm{~nm}$ peak on excitation at $254 \mathrm{~nm}$ as compared with the intensity of $542 \mathrm{~nm}$ emission in $\mathrm{Sr}_{0.99} \mathrm{~Tb}_{0.01} \mathrm{BPO}_{5}$. These results suggest the possibility of the potential of $\mathrm{SrBPO}_{5}-\mathrm{related}$ phosphors in tri-color lamps.
\end{abstract}

(C) 2005 Elsevier B.V. All rights reserved.

Keywords: $\mathrm{SrBPO}_{5}$; Luminescence; Energy transfer; Co-doping

\section{Introduction}

Since the introduction of tricolor fluorescent lamps based on rare earth ions, the research in the field of luminescence applications has been focused on developing new phosphors using rare earth ions. The newly developed devices, such as plasma display panels and field emission displays, also demand phosphors with improved properties. These displays require phosphors having good luminescence yield, small particles, and uniform spherical morphology [1]. Trivalent terbium ions based phosphors play an important role in the field of illumination and displays in view of its sharp green emission at around $545 \mathrm{~nm} . \mathrm{LaPO}_{4}, \mathrm{Y}_{2} \mathrm{SiO}_{5}$, $\mathrm{CeMgAl}_{11} \mathrm{O}_{19}$, and $\mathrm{GdMgB}_{5} \mathrm{O}_{10}$ are certain well-established phosphors based on energy transfer from $\mathrm{Ce}^{3+}$ to $\mathrm{Tb}^{3+}$ for

\footnotetext{
* Corresponding author. Tel.: +8862 23651428; fax: +886223623040.

E-mail address: chlu@ccms.ntu.edu.tw (C.-H. Lu).

${ }^{1}$ Permanent address: Radiochemistry Division, BARC, Mumbai 400085, India.
}

green emission in lamps [2]. The phosphor materials such as $\mathrm{LaOBr}: \mathrm{Tb}^{3+}, \mathrm{Ln}_{2} \mathrm{O}_{2} \mathrm{~S}: \mathrm{Tb}^{3+}$ (where $\mathrm{Ln}=\mathrm{Gd}, \mathrm{La}$, and $\mathrm{Y}$ ) and $\mathrm{Y}_{3} \mathrm{Al}_{5} \mathrm{O}_{12}: \mathrm{Tb}^{3+}$ are utilized in X-ray imaging and cathode ray tube $[3,4]$. Terbium doped matrices such as zirconium pyrophosphate, lanthanum borophosphate, gadolinium oxybromide, zinc silicate, calcium aluminate and vaterite, have lately been investigated for their spectroscopic properties [5-11].

Strontium borate phosphate $\left(\mathrm{SrBPO}_{5}\right)$ having a crystal structure corresponding to mineral stillwellite has been investigated in detail in recent years. The effects of doping $\mathrm{Eu}^{2+}$ and $\mathrm{Ce}^{3+}$ ions on the luminescent properties are reported in literature [12-14]. In the present work, luminescent properties of $\mathrm{Tb}^{3+}, \mathrm{Ce}^{3+}$ and $\mathrm{Na}^{+}$doped $\mathrm{SrBPO}_{5}$ are investigated. The photoluminescence investigations are performed to explore the luminescence and energy transfer characteristics of the doped ions in the host matrix. The observation of intense green luminescence from $\mathrm{SrBPO}_{5}: \mathrm{Tb}^{3+}, \mathrm{Ce}^{3+}$ and $\mathrm{Na}^{+}$on $254 \mathrm{~nm}$ excitation suggests a possibility of applying the newly developed phosphors to tri-color lamps. 


\section{Experimental}

$\mathrm{SrBPO}_{5}$-based phosphors were prepared via the solid-state reactions at high temperatures. For synthesizing $\mathrm{Sr}_{0.99} \mathrm{~Tb}_{0.01} \mathrm{BPO}_{5}$, reagent-grade $\mathrm{SrCO}_{3}, \mathrm{~Tb}_{4} \mathrm{O}_{7}$, $\left(\mathrm{NH}_{4}\right)_{2} \mathrm{HPO}_{4}$, and $\mathrm{H}_{3} \mathrm{BO}_{3}$ were thoroughly mixed by grinding. To investigate the effects of energy transfer and co-doping on the luminescent properties, $\mathrm{Na}^{+}$and $\mathrm{Ce}^{3+}$ ions were also incorporated with $\mathrm{Tb}^{3+}$ ions in the host matrix. $\mathrm{Na}_{2} \mathrm{HPO}_{4}$ and $\mathrm{CeO}_{2}$ were added along with other ingredients during grinding stage to obtain $\mathrm{Sr}_{0.94} \mathrm{~Tb}_{0.01} \mathrm{Na}_{0.05} \mathrm{BPO}_{5}, \quad \mathrm{Sr}_{0.94} \mathrm{~Tb}_{0.01} \mathrm{Ce}_{0.05} \mathrm{BPO}_{5}, \quad$ and $\mathrm{Sr}_{0.89} \mathrm{~Tb}_{0.01} \mathrm{Ce}_{0.05} \mathrm{Na}_{0.05} \mathrm{BPO}_{5}$. During the synthesis of $\mathrm{Sr}_{1-(x+y+z)} \mathrm{Tb}_{x} \mathrm{Ce}_{y} \mathrm{Na}_{z} \mathrm{BPO}_{5}$ (where $x=0.01, y=0$ or 0.05 and $z=0$ or 0.05 ), corresponding mixtures were initially heated at $400^{\circ} \mathrm{C}$ for $2 \mathrm{~h}$ in air, followed by thoroughly regrinding for $30 \mathrm{~min}$ before heating at higher temperatures. The $400^{\circ} \mathrm{C}$-heated mixtures of $\mathrm{Sr}_{0.99} \mathrm{~Tb}_{0.01} \mathrm{BPO}_{5}$, $\mathrm{Sr}_{0.95} \mathrm{Ce}_{0.05} \mathrm{BPO}_{5}$, and $\mathrm{Sr}_{0.94} \mathrm{~Tb}_{0.01} \mathrm{Ce}_{0.05} \mathrm{BPO}_{5}$ were heated at $1000{ }^{\circ} \mathrm{C}$ for $4 \mathrm{~h}$. For synthesizing $\mathrm{Sr}_{0.94} \mathrm{~Tb}_{0.01} \mathrm{Na}_{0.05} \mathrm{BPO}_{5}$ and $\mathrm{Sr}_{0.89} \mathrm{~Tb}_{0.01} \mathrm{Ce}_{0.05} \mathrm{Na}_{0.05} \mathrm{BPO}_{5}$, the $400{ }^{\circ} \mathrm{C}$-heated mixtures were further heated at $900{ }^{\circ} \mathrm{C}$ for $4 \mathrm{~h}$. As for the reducing treatment, the samples prepared in air were further heated at $900^{\circ} \mathrm{C}$ for $4 \mathrm{~h}$ in mixed gas $\left(\mathrm{N}_{2}\left(95\right.\right.$ vol.\%) and $\mathrm{H}_{2}$ $(5 \mathrm{vol} . \%))$. The crystal structures of the prepared powders were examined using an X-ray diffractometer (MAC M03 $\mathrm{XHF}$ ). Photoluminescence studies were conducted using a fluorescence spectrometer (Hitachi F-4500).

\section{Results and discussion}

\subsection{Luminescent characteristics of $\mathrm{Tb}^{3+}$ ions in $\mathrm{SrBPO}_{5}$}

Fig. 1 illustrates the XRD patterns for $1000^{\circ} \mathrm{C}$-heated $\mathrm{Sr}_{0.99} \mathrm{~Tb}_{0.01} \mathrm{BPO}_{5}$ (curve a) and $\mathrm{Sr}_{0.94} \mathrm{~Tb}_{0.01} \mathrm{Ce}_{0.05} \mathrm{BPO}_{5}$ (curve b), and $900{ }^{\circ} \mathrm{C}$-heated $\mathrm{Sr}_{0.94} \mathrm{~Tb}_{0.01} \mathrm{Na}_{0.05} \mathrm{BPO}_{5}$ (curve c) and $\mathrm{Sr}_{0.89} \mathrm{~Tb}_{0.01} \mathrm{Ce}_{0.05} \mathrm{Na}_{0.05} \mathrm{BPO}_{5}$ (curve d). All of the above samples were heated in air. The above XRD patterns are similar to that reported for the compound strontium borate phosphate (ICDD file No.18-1270), indicating the formation of the stillwellite phase. They could be indexed to a hexagonal space group. In the case of $\mathrm{Sr}_{0.99} \mathrm{~Tb}_{0.01} \mathrm{BPO}_{5}$, the unit cell parameters obtained are $a=b=0.68119 \mathrm{~nm}$ and $c=0.67696 \mathrm{~nm}$. Further heating these samples at $900^{\circ} \mathrm{C}$ in the reducing atmosphere did not result in any change in the XRD patterns.

Fig. 2 illustrates the emission spectra $\left(\lambda_{\text {excitation. }}=220 \mathrm{~nm}\right)$ for $900{ }^{\circ} \mathrm{C}$-heated $\mathrm{Sr}_{0.94} \mathrm{~Tb}_{0.01} \mathrm{Na}_{0 .} \mathrm{BPO}_{5}$ (curve a) and $1000{ }^{\circ} \mathrm{C}$-heated $\mathrm{Sr}_{0.99} \mathrm{~Tb}_{0.01} \mathrm{BPO}_{5}$ (curve b) prepared in air. The emission spectra show weak blue emission in the region of $380-450 \mathrm{~nm}$ and strong green emission in $475-630 \mathrm{~nm}$. The emission peaks at 385,417 and $438 \mathrm{~nm}$ are due to transitions from excited level ${ }^{5} \mathrm{D}_{3}$ to ${ }^{7} \mathrm{~F}_{6},{ }^{7} \mathrm{~F}_{5}$, and ${ }^{7} \mathrm{~F}_{4}$ levels of $\mathrm{Tb}^{3+}$ ions, respectively. The emission peaks due to ${ }^{5} \mathrm{D}_{4} \rightarrow{ }^{7} \mathrm{~F}_{6},{ }^{7} \mathrm{~F}_{5}$, ${ }^{7} \mathrm{~F}_{4}$, and ${ }^{7} \mathrm{~F}_{3}$ transitions are observed at $492,542,582$ and

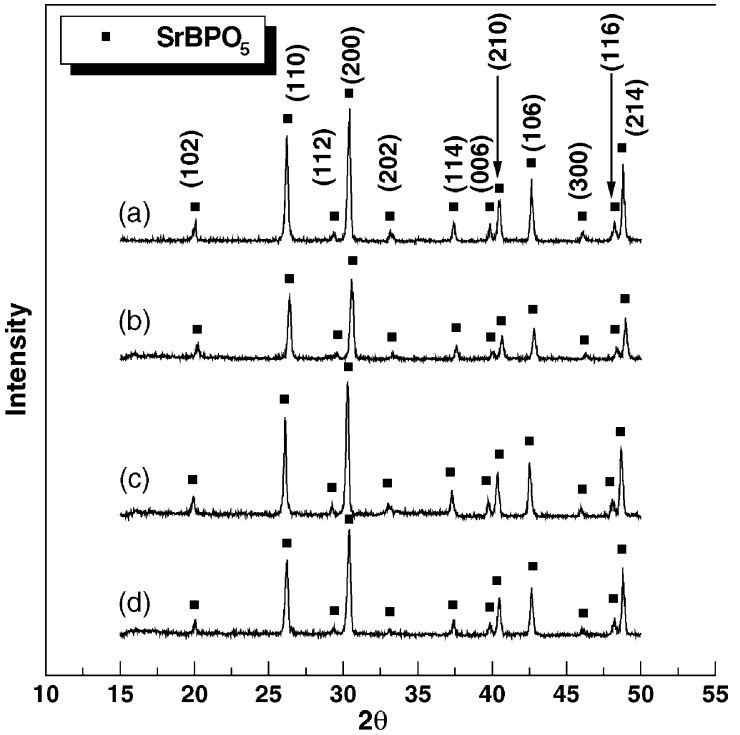

Fig. 1. XRD patterns of (a) $1000^{\circ} \mathrm{C}$-heated $\mathrm{Sr}_{0.99} \mathrm{~Tb}_{0.01} \mathrm{BPO}_{5}$ (air), (b) $1000^{\circ} \mathrm{C}$-heated $\mathrm{Sr}_{0.94} \mathrm{~Tb}_{0.01} \mathrm{Ce}_{0.05} \mathrm{BPO}_{5}$ (air), (c) $900^{\circ} \mathrm{C}$ heated $\mathrm{Sr}_{0.94} \mathrm{~Tb}_{0.01} \mathrm{Na}_{0.05} \mathrm{BPO}_{5}$ (air), and (d) $900{ }^{\circ} \mathrm{C}$-heated $\mathrm{Sr}_{0.89} \mathrm{~Tb}_{0.01} \mathrm{Ce}_{0.05} \mathrm{Na}_{0.05} \mathrm{BPO}_{5}$ (air).

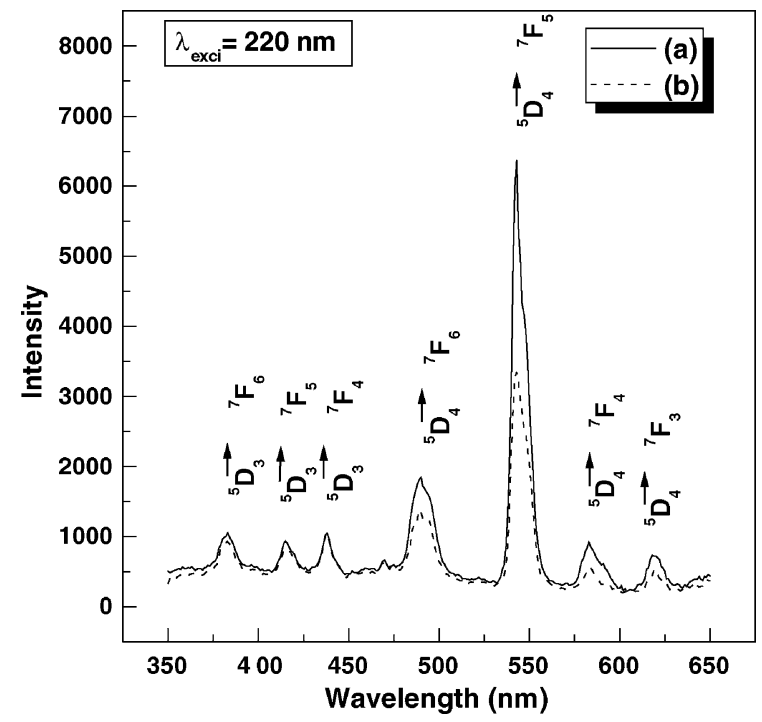

Fig. 2. Emission spectra $\left(\lambda_{\text {excitation }}=220 \mathrm{~nm}\right)$ of $(\mathrm{a}) \mathrm{Sr}_{0.94} \mathrm{~Tb}_{0.01} \mathrm{Na}_{0.05} \mathrm{BPO}_{5}$ heated at $900{ }^{\circ} \mathrm{C}$ in air and (b) $\mathrm{Sr}_{0.99} \mathrm{~Tb}_{0.01} \mathrm{BPO}_{5}$ heated at $1000^{\circ} \mathrm{C}$ in air.

$618 \mathrm{~nm}$, respectively [16]. Owing to the crystal field splitting of the levels into several sublevels, the observed spectra are complicated in appearance. The emission intensity of $542 \mathrm{~nm}$ peak corresponding to ${ }^{5} \mathrm{D}_{4} \rightarrow{ }^{7} \mathrm{~F}_{5}$ transition shows a two-fold increase in $\mathrm{Sr}_{0.94} \mathrm{~Tb}_{0.01} \mathrm{Na}_{0.05} \mathrm{BPO}_{5}$ in comparison with that of $\mathrm{Sr}_{0.99} \mathrm{~Tb}_{0.01} \mathrm{BPO}_{5}$.

Fig. 3 illustrates the excitation spectra $\left(\lambda_{\text {emission }}=542 \mathrm{~nm}\right)$ for $900{ }^{\circ} \mathrm{C}$-heated $\mathrm{Sr}_{0.94} \mathrm{~Tb}_{0.01} \mathrm{Na}_{0.05} \mathrm{BPO}_{5}$ (curve a) and $1000{ }^{\circ} \mathrm{C}$-heated $\mathrm{Sr}_{0.99} \mathrm{~Tb}_{0.01} \mathrm{BPO}_{5}$ (curve b) prepared in air. The inset in the figure reveals weak excitation peaks observed for these phosphors in the wavelength range of $250-400 \mathrm{~nm}$. A strong excitation peak at $220 \mathrm{~nm}$ along with a number 


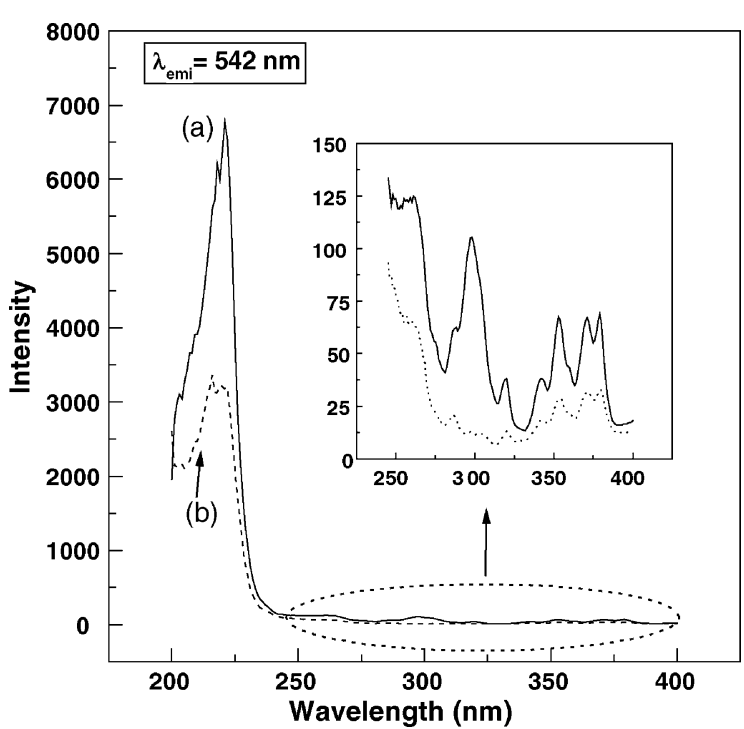

Fig. 3. Excitation spectra $\left(\lambda_{\text {emission }}=542 \mathrm{~nm}\right)$ of (a) $\mathrm{Sr}_{0.94} \mathrm{~Tb}_{0.01} \mathrm{Na}_{0.05} \mathrm{BPO}_{5}$ heated at $900{ }^{\circ} \mathrm{C}$ in air and (b) $\mathrm{Sr}_{0.99} \mathrm{~Tb}_{0.01} \mathrm{BPO}_{5}$ heated at $1000^{\circ} \mathrm{C}$ in air. The inset: enlarged excitation spectra at $250-400 \mathrm{~nm}$.

of comparatively weak excitation peaks in the wavelength range of $280-380 \mathrm{~nm}$ are observed. The relatively strong excitation band at $220 \mathrm{~nm}$ can be attributed to $4 \mathrm{f}^{8} \rightarrow 4 \mathrm{f}^{7} 5 \mathrm{~d}^{1}$ transition [15]. The weak excitations shown in the inset are due to various excited states of $\mathrm{Tb}^{3+}$ ions belonging to $4 \mathrm{f}^{8}$ electronic configuration, including the ${ }^{5} \mathrm{D}_{3}$ excited state at $380 \mathrm{~nm}$. The excitation spectra also reveal a similar degree of enhancement in the intensity, as a result of co-doping $\mathrm{Na}^{+}$and $\mathrm{Tb}^{3+}$ ions in $\mathrm{Sr}_{0.94} \mathrm{~Tb}_{0.01} \mathrm{Na}_{0.05} \mathrm{BPO}_{5}$. Introduction of $\mathrm{Ce}^{3+}$ or $\mathrm{Tb}^{3+}$ ions without the coexistence of charge compensating ions requires the formation of cation vacancies. Moreover, heating in air produces oxygen vacancies as well. It is probable that the starting material with the composition of $\mathrm{Sr}_{0.94} \mathrm{~Tb}_{0.01} \mathrm{Na}_{0.05} \mathrm{BPO}_{5}$ can lead to $\mathrm{Sr}_{0.98} \mathrm{~Tb}_{0.01} \mathrm{Na}_{0.02} \mathrm{BPO}_{5}$ formation with excess $\mathrm{Na}, \mathrm{B}$ and $\mathrm{P}$ either volatilized or present as a minor phase that undetected by XRD. In that case, the observed enhancement in the $\mathrm{Tb}^{3+}$ emission can be attributed to the charge compensation by $\mathrm{Na}^{+}$ions that alleviates the need for formation of defects. These defects, such as cation vacancies and oxygen vacancies, are expected in the case of $\mathrm{Sr}_{0.99} \mathrm{~Tb}_{0.01} \mathrm{BPO}_{5}$ samples which usually lead to non-radiative energy losses.

\subsection{Luminescent characteristics of $\mathrm{Ce}^{3+}$ ions in $\mathrm{SrBPO}_{5}$}

The luminescent characteristics of $\mathrm{Ce}^{3+}$ ions are known to depend upon whether the charge compensatory vacancy is associated with $\mathrm{Ce}^{3+}$ ions in the cases of similar aliovalent substitution $[17,18]$. Our earlier investigations on $\mathrm{Sr}_{0.95} \mathrm{Ce}_{0.05} \mathrm{BPO}_{5}$ have revealed that $\mathrm{Ce}^{3+}$ ions situated at $\mathrm{Sr}^{2+}$ sites with no associated vacancy show a broad emission peak at $317 \mathrm{~nm}$ with a shoulder around $330 \mathrm{~nm}$ upon $275 \mathrm{~nm}$ excitation [19]. On the other hand, $\mathrm{Ce}^{3+}$ ions substituting at $\mathrm{Sr}^{2+}$ sites with associated vacancy show red shifted

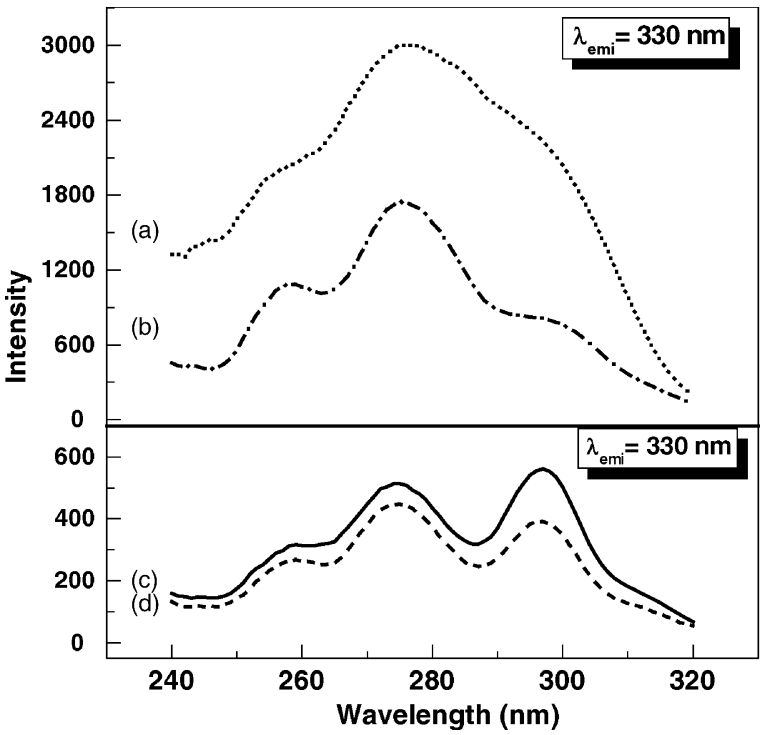

Fig. 4. Excitation spectra $\left(\lambda_{\text {emission }}=330 \mathrm{~nm}\right)$ of (a) $900{ }^{\circ} \mathrm{C}$-heated $\mathrm{Sr}_{.89} \mathrm{~Tb}_{.01} \mathrm{Ce} .05 \mathrm{Na}_{0.05} \mathrm{BPO}_{5}$ (reducing atmosphere), (b) $900{ }^{\circ} \mathrm{C}$ heated $\mathrm{Sr}_{0.94} \mathrm{~Tb}_{0.01} \mathrm{Ce}_{0.05} \mathrm{BPO}_{5}$ (reducing atmosphere), (c) $900{ }^{\circ} \mathrm{C}$ heated $\mathrm{Sr}_{0.89} \mathrm{~Tb}_{0.01} \mathrm{Ce}_{0.05} \mathrm{Na}_{0.05} \mathrm{BPO}_{5}$ (air), and (d) $1000{ }^{\circ} \mathrm{C}$-heated $\mathrm{Sr}_{0.94} \mathrm{~Tb}_{0.01} \mathrm{Ce}_{0.05} \mathrm{BPO}_{5}$ (air).

emission with peaks at 330 and $350 \mathrm{~nm}$ upon excitation at $295 \mathrm{~nm}$

\subsection{Energy transfer from $\mathrm{Ce}^{3+}$ ions to $\mathrm{Tb}^{3+}$ ions in $\mathrm{SrBPO}_{5}$}

Fig. 4 illustrates the excitation spectra for $\mathrm{Ce}^{3+}$ ions for $\lambda_{\text {emission }}=330 \mathrm{~nm}$ in $900^{\circ} \mathrm{C}$-heated $\mathrm{Sr}_{0.89} \mathrm{~Tb}_{0.01}$ $\mathrm{Ce}_{0.05} \mathrm{Na}_{0.05} \mathrm{BPO}_{5}$ and $1000^{\circ} \mathrm{C}$-heated $\mathrm{Sr}_{0.94} \mathrm{~Tb}_{0.01} \mathrm{Ce}_{0.05}$ $\mathrm{BPO}_{5}$ samples prepared in the reducing atmosphere (curves $\mathrm{a}$ and b) and in air (curves c and d). For the samples prepared in air, the excitation peaks are observed at 295, 275 and $260 \mathrm{~nm}$ with the former two peaks comparable in intensity; while, the excitation peak at $260 \mathrm{~nm}$ is relatively weak. The excitation spectra for the samples prepared in the reducing atmosphere (curve $a$ and $b$ ) show strong intensities. The positions of the excitation peaks of these samples are nearly the same. Among three excitation peaks illustrated in curves $a$ and $b$, the one at $275 \mathrm{~nm}$ is the most intense, while those at 260 and $295 \mathrm{~nm}$ appear as shoulders to the peak at $275 \mathrm{~nm}$. The emission intensities of $\mathrm{Ce}^{3+}$ ions in the samples heated in the reducing atmosphere are noted to increase, suggesting nearly complete reduction of $\mathrm{Ce}^{4+}$ ions to $\mathrm{Ce}^{3+}$ ions.

Fig. 5 shows the excitation spectra of $\mathrm{Tb}^{3+}$ ions at $542 \mathrm{~nm}$ emission in different phosphors. The excitation peaks in the 240-380 nm region are relatively weak for $1000^{\circ} \mathrm{C}$-heated $\mathrm{Sr}_{0.99} \mathrm{~Tb}_{0.01} \mathrm{BPO}_{5}$ prepared in air (curve e). For the other samples co-doped with $\mathrm{Ce}^{3+}$ ions, additional strong excitation peaks occur in the region of $240-320 \mathrm{~nm}$. Additional excitation peaks at 275 and $295 \mathrm{~nm}$ are observed for $900^{\circ} \mathrm{C}$-heated $\mathrm{Sr}_{0.89} \mathrm{~Tb}_{0.01} \mathrm{Ce}_{0.05} \mathrm{Na}_{0.05} \mathrm{BPO}_{5}$ (curve c) and $1000^{\circ} \mathrm{C}$-heated 


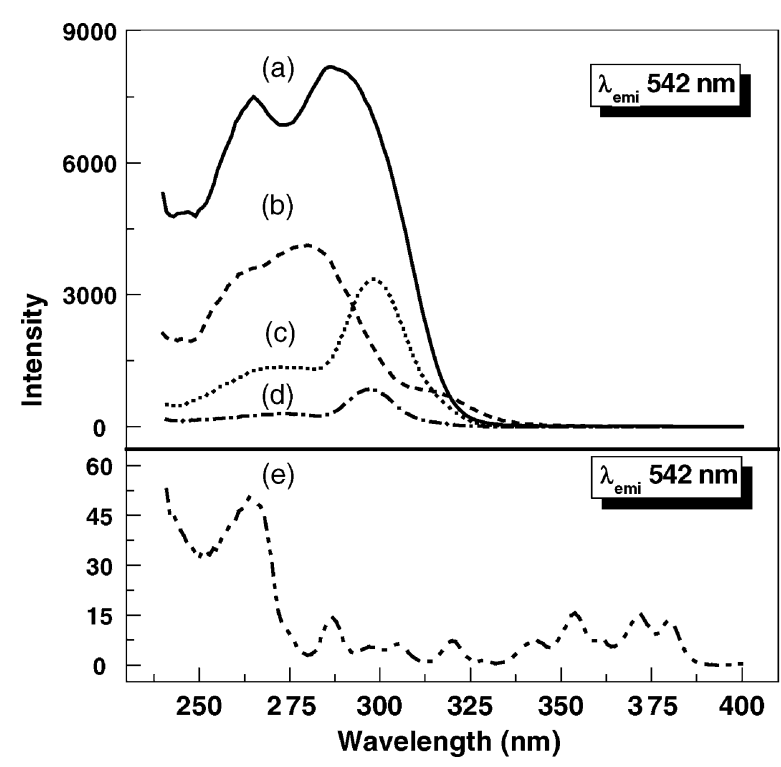

Fig. 5. Excitation spectra $\left(\lambda_{\text {emission }}=542 \mathrm{~nm}\right)$ of (a) $900^{\circ} \mathrm{C}$-heated $\mathrm{Sr}_{0.89} \mathrm{~Tb}_{0.01} \mathrm{Ce}_{0.05} \mathrm{Na}_{0.05} \mathrm{BPO}_{5}$ (reducing atmosphere), (b) $900{ }^{\circ} \mathrm{C}$ heated $\mathrm{Sr}_{0.94} \mathrm{~Tb}_{0.01} \mathrm{Ce}_{0.05} \mathrm{BPO}_{5}$ (reducing atmosphere), (c) $900^{\circ} \mathrm{C}$ heated $\mathrm{Sr}_{0.89} \mathrm{~Tb}_{0.01} \mathrm{Ce}_{0.05} \mathrm{Na}_{0.05} \mathrm{BPO}_{5} \quad$ (air), (d) $1000^{\circ} \mathrm{C}$-heated $\mathrm{Sr}_{0.94} \mathrm{~Tb}_{0.01} \mathrm{Ce}_{0.05} \mathrm{BPO}_{5}$ (air), and (e) $1000^{\circ} \mathrm{C}$-heated $\mathrm{Sr}_{0.99} \mathrm{~Tb}_{0.01} \mathrm{BPO}_{5}$ (air).

$\mathrm{Sr}_{0.94} \mathrm{~Tb}_{0.01} \mathrm{Ce}_{0.05} \mathrm{BPO}_{5}$ (curve d) prepared in air as a result of co-doping with cerium ions. These peaks, observed for $\mathrm{Tb}^{3+}$ emission, correspond to the excitation bands of $\mathrm{Ce}^{3+}$ ions [19]. This observation clearly indicates the energy transfer amongst these ions.

For the samples prepared in the reducing atmosphere, shift in peak positions and changes and increase in relative excitation intensities are observed. Intense excitation peaks are found at 260 and $280 \mathrm{~nm}$ for $\mathrm{Sr}_{0.94} \mathrm{~Tb}_{0.01} \mathrm{Ce}_{0.05} \mathrm{BPO}_{5}$ (curve b) prepared in the reducing atmosphere. These correspond to the $\mathrm{Ce}^{3+}$ excitation peaks. However, for $\mathrm{Sr}_{0.89} \mathrm{~Tb}_{0.01} \mathrm{Ce}_{0.05} \mathrm{Na}_{0.05} \mathrm{BPO}_{5}$ (curve a) prepared in the reducing atmosphere, peaks due to $\mathrm{Ce}^{3+}$ absorption are observed at 285 and $265 \mathrm{~nm}$. This shift can be explained by the changed crystal field environment of $\mathrm{Ce}^{3+}$ ions because of the co-doping of smaller $\mathrm{Na}^{+}$ions in $\mathrm{SrBPO}_{5}$. The peak shifts and change in relative intensities of the excitation peaks in curves $\mathrm{c}$ and $\mathrm{d}$ are presumably due to the contribution from $\mathrm{Ce}^{3+}$ ions occupying sites with and without charge compensating cation/oxygen vacancies in varying proportion.

\subsection{Effects of co-doping of $\mathrm{Na}^{+}$ions on the luminescent properties}

The emission spectra for the prepared samples upon excitation at $254 \mathrm{~nm}$ were recorded for the interest in mercury-based fluorescent lamps and are shown in Fig. 6. Curves $\mathrm{a}$ and $\mathrm{b}$ illustrate the emission spectra obtained for $\mathrm{Sr}_{0.89} \mathrm{~Tb}_{0.01} \mathrm{Ce}_{0.05} \mathrm{Na}_{0.05} \mathrm{BPO}_{5}$ and $\mathrm{Sr}_{0.94} \mathrm{~Tb}_{0.01} \mathrm{Ce}_{0.05} \mathrm{BPO}_{5}$ heated at $900{ }^{\circ} \mathrm{C}$ in the reducing atmosphere, respectively. The emission spectra for $\mathrm{Sr}_{0.94} \mathrm{~Tb}_{0.01} \mathrm{Ce}_{0.05} \mathrm{BPO}_{5}$

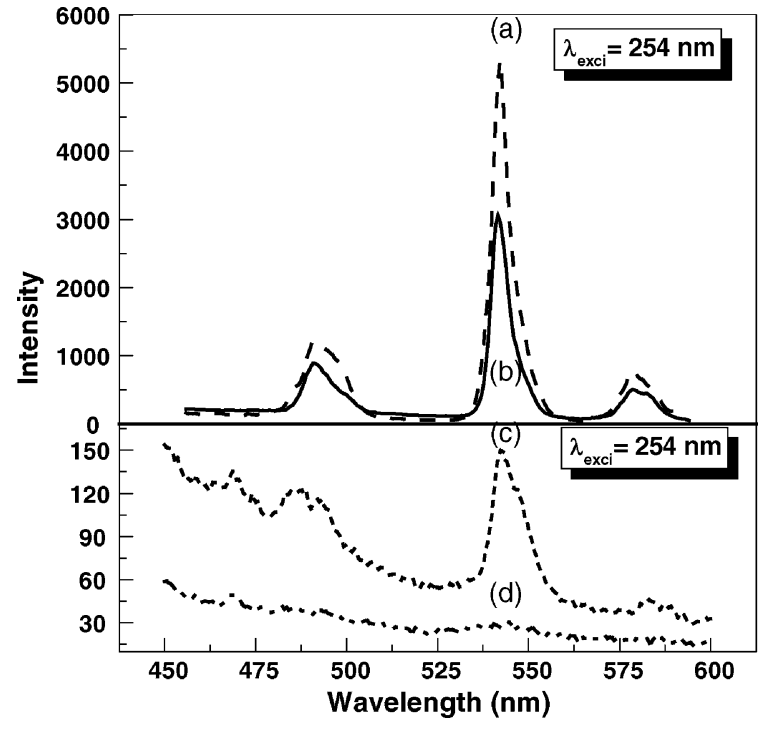

Fig. 6. Emission Spectra $\left(\lambda_{\text {excitation }}=254 \mathrm{~nm}\right)$ of (a) $900^{\circ} \mathrm{C}$-heated $\mathrm{Sr}_{0.89} \mathrm{~Tb}_{0.01} \mathrm{Ce}_{0.05} \mathrm{Na}_{0.05} \mathrm{BPO}_{5}$ (reducing atmosphere), (b) $900{ }^{\circ} \mathrm{C}$-heated $\mathrm{Sr}_{0.94} \mathrm{~Tb}_{0.01} \mathrm{Ce}_{0.05} \mathrm{BPO}_{5}$ (reducing atmosphere), (c) $1000^{\circ} \mathrm{C}$-heated $\mathrm{Sr}_{0.94} \mathrm{~Tb}_{0.01} \mathrm{Ce}_{0.05} \mathrm{BPO}_{5}$ (air), and (d) $1000{ }^{\circ} \mathrm{C}$-heated $\mathrm{Sr}_{0.99} \mathrm{~Tb}_{0.01} \mathrm{BPO}_{5}$ (air).

and $\mathrm{Sr}_{0.99} \mathrm{~Tb}_{0.01} \mathrm{BPO}_{5}$ prepared in air are shown in curves $\mathrm{c}$ and $\mathrm{d}$, respectively. Upon excitation at $254 \mathrm{~nm}$, the green emission at $542 \mathrm{~nm}$ increases by nearly 100 -fold in $\mathrm{Sr}_{0.94} \mathrm{~Tb}_{0.01} \mathrm{Ce}_{0.05} \mathrm{BPO}_{5}$ (curve b) and 170 folds in $\mathrm{Sr}_{0.89} \mathrm{~Tb}_{0.01} \mathrm{Ce}_{0.05} \mathrm{Na}_{0.05} \mathrm{BPO}_{5}$ (curve a) in comparison with $\mathrm{Sr}_{0.99} \mathrm{~Tb}_{0.01} \mathrm{BPO}_{5}$ (curve d) prepared in air. The intensity of the emission peak of $\mathrm{Tb}^{3+}$ ions at $542 \mathrm{~nm}$ in $\mathrm{Sr}_{0.89} \mathrm{~Tb}_{0.01} \mathrm{Ce}_{0.05} \mathrm{Na}_{0.05} \mathrm{BPO}_{5}$ phosphor prepared in the reducing atmosphere was compared with that of the commercial green phosphor $\mathrm{LaPO}_{4}: \mathrm{Ce}^{3+}, \mathrm{Tb}^{3+}$ (Nichia, Japan), and the relative luminescence yield was found to be about $10 \%$.

As illustrated in Figs. 2 and 6, the incorporation of sodium ions as co-dopants in the respective sample does not lead to changes in emission wavelengths; however, increased luminescence of $\mathrm{Tb}^{3+}$ and $\mathrm{Ce}^{3+}$ ions is observed. The enhancement in luminescence can arise due to several reasons such as energy transfer, decreased formation of charge compensating cation vacancies/oxygen vacancies due to $\mathrm{Na}^{+}$ion codoping, and increased concentration of emitting ions. The monovalent sodium ions cannot involve directly in the energy transfer process, since their closed shell configuration cannot have matching energy levels with those of $\mathrm{Tb}^{3+}$ and $\mathrm{Ce}^{3+}$ ions. An increase in luminescence intensity of $\mathrm{Ce}^{3+}$ ions due to co-doping of monovalent lithium ions has been reported in lanthanum phosphate and is ascribed to the energy transfer from $\mathrm{Ce}^{4+}$ to $\mathrm{Ce}^{3+}$ ions facilitated by co-doping of $\mathrm{Li}^{+}$ions [20]. The preparation of the phosphors in the reducing atmosphere result in reduction of $\mathrm{Ce}^{4+}$ and $\mathrm{Tb}^{4+}$ ions to $\mathrm{Ce}^{3+}$ and $\mathrm{Tb}^{3+}$ ions, respectively. Since $\mathrm{Ce}^{4+}$ ions are expected to be absent in $\mathrm{Sr}_{0.94} \mathrm{~Tb}_{0.01} \mathrm{Ce}_{0.05} \mathrm{BPO}_{5}$ and $\mathrm{Sr}_{0.89} \mathrm{~Tb}_{0.01} \mathrm{Ce}_{0.05} \mathrm{Na}_{0.05} \mathrm{BPO}_{5}$ prepared in the reducing atmosphere, the observed luminescence enhancement cannot 
be attributed to the energy transfer from $\mathrm{Ce}^{4+}$ ions. Furthermore, similar luminescence enhancement with co-doping of $\mathrm{Na}^{+}$ions has been reported in $\mathrm{CaSO}_{4}: \mathrm{Eu}^{3+}$, wherein this has been attributed to the decreased concentration of vacancies [21].

Hence the luminescence enhancement observed for the $\mathrm{Sr}_{0.89} \mathrm{~Tb}_{0.01} \mathrm{Ce}_{0.05} \mathrm{Na}_{0.05} \mathrm{BPO}_{5}$ samples prepared in the reducing atmosphere is understood as due to co-doping of $\mathrm{Na}^{+}$ ions. Co-doping of $\mathrm{Na}^{+}$ions with $\mathrm{Ce}^{3+}$ and $\mathrm{Tb}^{3+}$ ions in the samples results in a significant reduction of charge compensating vacancies, which are expected to be formed in the host lattice. This is expected to cause a significant reduction in non-radiative transitions and lead to the enhanced luminescence intensity.

\section{Conclusion}

The trivalent terbium ions in the $\mathrm{SrBPO}_{5}$ host show luminescence arising from various ${ }^{5} \mathrm{D}_{3}$ and ${ }^{5} \mathrm{D}_{4} \rightarrow{ }^{7} \mathrm{~F}_{\mathrm{J}}$ transitions of $\mathrm{Tb}^{3+}$ ions upon excitation at $220 \mathrm{~nm}$. The excitation band at $220 \mathrm{~nm}$ is ascribed to the lowest $4 \mathrm{f}^{8} \rightarrow 4 \mathrm{f}^{7} 5 \mathrm{~d}^{1}$ transition in the host. As a result of co-doping $\mathrm{Ce}^{3+}$ with $\mathrm{Tb}^{3+}$ ions in the host of $\mathrm{SrBPO}_{5}$, the excitation spectra of $\mathrm{Tb}^{3+}$ ions show additional intense excitation occurring at $240-300 \mathrm{~nm}$ due to energy transfer from $\mathrm{Ce}^{3+}$ to $\mathrm{Tb}^{3+}$ ions. With excitation at $240-300 \mathrm{~nm}$, increased luminescence is observed for $\mathrm{Sr}_{0.94} \mathrm{~Tb}_{0.01} \mathrm{Ce}_{0.05} \mathrm{BPO}_{5}$ and $\mathrm{Sr}_{0.89} \mathrm{~Tb}_{0.01} \mathrm{Ce}_{0.05} \mathrm{Na}_{0.05} \mathrm{BPO}_{5}$ synthesized in the reducing atmosphere. The luminescence enhancement in these phosphors is attributed to the reduction of charge compensating cation vacancies/oxygen vacancies, resulting in higher concentration of $\mathrm{Ce}^{3+}$ ions and consequent energy transfer to $\mathrm{Tb}^{3+}$ ions. $\mathrm{Sr}_{0.89} \mathrm{~Tb}_{0.01} \mathrm{Ce}_{0.05} \mathrm{Na}_{0.05} \mathrm{BPO}_{5}$ prepared in the reducing atmosphere shows more than twoorder magnitude increase in $254 \mathrm{~nm}$ excited green emission of $\mathrm{Tb}^{3+}$ ions in comparison with $\mathrm{Sr}_{0.99} \mathrm{~Tb}_{0.01} \mathrm{BPO}_{5}$ prepared in air. It is revealed that $\mathrm{SrBPO}_{5}$-related phosphors exhibit enhanced luminescence and can be utilized as green phosphors in tricolor lamps.

\section{References}

[1] Y.C. Kang, I.W. Lenggoro, S.B. Park, K. Okuyama, Mater. Res. Bull. 35 (2000) 789.

[2] S. Kamiya, H. Mizumo, in: S. Shionoya, W.M. Yen (Eds.), Phosphor Handbook, CRC Press, Boca Raton, 1998, p. 393.

[3] N. Miura, in: S. Shionoya, W.M. Yen (Eds.), Phosphor Handbook, CRC Press, Boca Raton, 1998, p. 524.

[4] K. Ohno, in: S. Shionoya, W.M. Yen (Eds.), Phosphor Handbook, CRC Press, Boca Raton, 1998, p. 493.

[5] V.A. Pelova, L.S. Grigorov, J. Lumin. 72-74 (1997) 241.

[6] S.J. Ding, D.W. Zhang, P.F. Wang, J.T. Wang, Mater. Chem. Phys. 68 (2001) 98.

[7] F.S. Kao, T.M. Chen, J. Lumin. 96 (2001) 261.

[8] C.H. Kam, S. Buddhudu, Mater. Lett. 54 (2002) 337.

[9] H.X. Zhang, S. Buddhudu, C.H. Kam, Y. Zhou, Y.L. Lam, K.S. Wong, B.S. Ooi, S.L. Ng, W.W. Que, Mater. Chem. Phys. 68 (2001) 31.

[10] D.D. Jia, J. Zhu, B.Q. Wu, J. Lumin. 93 (2001) 107

[11] Y. Kojima, S. Doi, T. Yasue, J. Ceram. Soc. Jpn. 110 (2002) 755.

[12] A. Karthikeyani, R. Jagannathan, J. Lumin. 86 (2000) 79.

[13] L.C. Nehru, K. Marimuthu, M. Jayachandran, Chung-Hsin-Lu, R. Jagannathan, J. Phys. D: Appl. Phys. 34 (2001) 2599.

[14] H.B. Liang, Q. Su, Y. Tao, T.D. Hu, T. Liu, S.L.E. Shulin, J. Phys. Chem. Solids 63 (2002) 719 .

[15] T. Kano, in: S. Shionoya, W.M. Yen (Eds.), Phosphor Handbook, CRC Press, Boca Raton, 1998, p. 185.

[16] G.H. Dieke, Spectra and Energy Levels of Rare Earth Ions in Crystals, Interscience Publishers, 1968, p. 253.

[17] J.W.M. Verwey, G.J. Dirksen, G. Blasse, J. Phys. Chem. Solids 53 (1992) 367.

[18] V.P. Dotsenko, I.V. Berezovskaya, N.P. Efryushina, A.S. Voloshinovskii, P. Dorenbos, C.W.E. Van Eijk, J. Lumin. 93 (2001) 137.

[19] C.H. Lu, S.V. Godbole, J. Mater. Res. 19 (2004) 2336.

[20] J. Lin, G. Yao, Y. Dong, B. Park, M. Su, J. Alloys Compd. 225 (1995) 124.

[21] D. Vandervoort, G. Blasse, J. Solid State Chem. 87 (1990) 350. 